\title{
Indhold
}

Dette nummer fortsatter med at have fokus på udstillingsmediets virkemidler og dets samspil med publikum.

Der har varet stor interesse for temaet, og de optagne artikler kommer ind på mange forskellige aspekter og rummer spandende og provokende synspunkter. Men temaet er dermed langt fra udtømt, og vi håber - som også Marc Maure, inviteret medredaktor og ophavsmanden til temaet, skriver i nedenstående forord - at Nordisk Museologi hermed har skabt grobund for mere systematisk forskning $i$ de nordiske landes brug af udstillingsmediet, historisk og pa tvars af landegranser og fag.

Ane Hejlskov Larsen

\section{Den fraværende utstillingshistorie}

MARc Maure

"Jag har många starka utställningsminne" skriver Eva Persson. " "Ibland önskar jag att jag kunde få dem historiskt belysta, insatta i svenskt och internationellt sammanhang. Men den boken över Sveriges utställningshistoria finns intet. Om man anstänger sig kan man få ett hum om utställningsutvecklingen i Sverige i enskilda museers jubileumsskrifter och årsböcker."

Hva med de andre nordiske land? Har de skrevet sin egen utstillingshistorie? Jeg vil tro at Sverige tross alt har gjort mest med hensyn til publikasjoner om utstillingsspørsmål. Allerede i 1970-årene utmerket landet seg internasjonalt med et aktivt utstillingsmiljø og mange interessante utgivelser, blant annet med Riksutstâllningar som drivkraft.

Det er et faktum at utstillingsspørsmål er et forsømt studiefelt; det gjelder internasjonalt, men med nasjonale variasjoner. Det finnes en mengde tekster av beskrivende karakter om utstillinger i museene, men analysene er mangelfulle. Vår kunnskap om feltet er sporadisk, fragmentarisk. Vi vet en del om enkelte institusjoner eller perioder, og lite om resten. Vi mangler dypere innsikt, forståelse om fenomenet. Vi savner den systematiske oversikten over geografiske eller institusjonelle variasjoner, de ulike genrene og stilene, m.v.

Det er egentlig paradoksalt at museumsfolk har vist så lite interesse for den historiske utviklingen av utstillingene, et medium som er et så sentralt element i museenes egenart og virksomhet. De kan dessuten oppføre seg som vandaler $\mathrm{i}$ egen institusjon ved å rive ned de gamle utstillingene uten å ta hensyn til deres 
2 kulturhistoriske, narrative eller estetiske verdier.

Det er paradoksalt at museumsfolk, som ellers er så opptatt av å definere alt mellom himmel og jord som kulturminne, har vist så liten respekt for utstillingene som forgjengerne skapte. Det som har blitt tatt vare på, i form av utstillingsfragmenter, bilder og beskrivelser, er forholdsvis lite systematisert og studert. Derfor er vårt syn på disse utstillingene ofte preget av uklare og feilaktige forestillinger. Vi tror gjerne at de var primitive og besto av tilfeldige sammenstillinger, eller kjedelige typologiske oppstillinger av gjenstander. ${ }^{2}$

På et mer praktisk nivå, har denne historieløsheten negative konsekvenser for utstillingsproduksjonens mangfold og kvalitet, fordi kuratorer og formgivere ikke har tilgang til en bred repertoar av konsepter og former utviklet gjennom mediets historie. Ofte kan jeg tenke, når jeg besøker en nyere produsert utstilling, at resultatet kunne ha vært så mye bedre, hvis de som hadde laget den hadde hatt bedre kjennskap til tidligere erfaringer, så som enkelte produksjoner fra 1970-årene, for ikke å snakke om eksperimentene fra 1930-årene.

Sett $\mathrm{i}$ et bredere perspektiv, representerer museumsutstillingen bare én kategori eller ett område av utstillingsmediets allsidige anvendelser i mange ulike kontekster. Jeg er av den oppfatning at utstillingsmediet, et kommunikasjonssystem karakterisert ved iscenesetting av objekter i et rom, er verdens eldste og mest anvendte massemedium, og jeg har derfor vanskeligheter med å forstå at det ikke har vært gjenstand for større interesse.

It is remarkable and in fact paradoxical that the exhibition as cultural phenomenon has aroused so little attention at the theoretical level. Exhibitions are a familiar sight in everyday life and play an important part in social communication. Cultural institutions, museums and galleries present exhibitions. In our daily lives too, in shops, homes, on the street in the countryside etc. We are constantly the creators or users of exhibitions. ${ }^{3}$

Dette skrev jeg i 1995, og mye positivt har selvsagt skjedd siden, men kanskje ikke så mye som en kunne ønske seg. For det første har vi opplevd en enorm internasjonal øking i antall publikasjoner av museologisk karakter, og i et slikt omfang at det er vanskelig å holde seg orientert. For det andre, er temaet nå blitt mer populært i universitetsmiljøer; før var det i hovedsak museumsfolk som skrev om museums- og utstillingspørssmål, med stor innsikt men ikke alltid med den nødvendige avstand til stoffet.

Tidligere $\mathrm{i}$ år hadde jeg en samtale med den franske etnologen André Desvallées - pensjonert museumsdirektør og internasjonalt kjent som redaktør og forfatter av museologisk litteratur - om boka hans om det omstridte $\mathrm{Mu}$ sée du Quai Branly i Paris, ${ }^{4}$ og om museologiske publikasjoner i Frankrike mer generelt.

Han mente at det var nå kommet mange gode publikasjoner, men samtidig at situasjonen var preget av at universitetenes $\mathrm{krav}$ til økt publisering hadde ført til at ansatte og studenter i stadig økende grad valgte museene og utstillingene som studieobjekter. Resultatet var en stor øking i mengden av stoffet som var publisert, mens kvaliteten kunne være skuffende. Ikke så sjelden fikk en inntrykk av at det var bare gammel kunnskap som var presentert $\mathrm{i}$ ny emballasje. De faglige analyseredskapene kunne være i orden, men problemet var ofte et svakt empirigrunnlag i mangel av eksisterende kildemateriale og faglitteratur. En annen ting er at mange studier bare omhandlet "utenforliggende" faktorer av økonomisk, idéhistorisk 
eller av annen karakter, uten å kunne relatere dem til selve utstillingen som uttrykk. Men dette var nok barnesykdommer i et studiefelt i full utvikling.

I senere tid et det kommet publikasjoner av høy kvalitet, som kombinerer teoretiske innsikt med empirisk kunnskap, og viser hva en utstillingshistorie kan være. Jeg har her spesielt lyst til å nevne og anbefale følgende bøker, som hver på sin måte omhandler en periode som var en gullalder i utstillingshistorien. Mark Sandbergs Living pictures and missing persons; mannequins, museums and modernity, ${ }^{5}$ et originalt og spesielt spennende studium av utstillingene i de første skandinaviske folke- og friluftsmuseene, en banebrytende muse-umsmodell som påvirket utviklingen internasjonalt. Mary Anne Staniszewskis The Power of Display: A History of Exhibition Installations at the Museum of Modern Art, ${ }^{6}$ en presentasjon av utstillingseksperimentene som den internasjonale avantgarde gjennomførte i 1920-30 årene med stor mediebevissthet og omfattende samfunnsengasjement.

\section{NOTER}

1. Har Sverige en utställningshistoria, Utställningsestetiskt Forum, 01.10.2008, www.ueforum.se

2. Marc Maure, "Bonder, ånder, dukker og skuespillere i de første folkemuseene", Nordisk Museologi, 2004/1.

3. Marc Maure, "The Exhibition as Theater - on the Staging of Museum Objects", Nordisk Museo$\log$, 1995/2.

4. André Desvallées, Quai Branly: un miroir aux alouettes? Ethnographie et "arts premiers", Paris 2007.

5. Princeton University Press, 2002.

6. MIT Press, Cambridge, 2001.
Sverige har en tidskrift som regelbundet och kritisk gransker sakmuseernas utställningar

Det är nättidskriften Utställningsestetiskt forum - www.UEForum.se

Som enda tidskrift i Sverige tar UEForum.se utställningsmediet på allvar.

Genom recensioner, reportage, samtal, teoretiska essäer, litteraturbevakning och debattartiklar ökar Utställningsestetiskt forum den offentliga samtalet om sakmuseernas utställningar.

Vi menar att kritiska resonemang kring museernas utställningsverksamhet höjer kraven och därmed kvalitén på de många hundratals natur- och kulturhistoriska utställningar som varje år produceras i Sverige.

Vill du att UEForum skall recensera fler utställningar och engagera skarpare kritiker, tipsa oss gärna om skribenter.

Kanske vill du själv medverka?!

Hör av dig till chefredaktören

Eva Persson

eva@ueforum.se 